\title{
Correction to: Beryl occurrences in the granitic complex of Guerioune, Laouni, Southeastern Algeria: electron microprobe, infrared spectroscopy, and fluid inclusions data
}

\author{
Ahmed Hamis $^{1,2} \cdot$ Mokrane Kesraoui $^{2} \cdot$ Abdelhak Boutaleb $^{2} \cdot$ Yves Fuchs $^{3} \cdot$ Christian Marignac $^{4}$ \\ Published online: 22 March 2021 \\ (C) Saudi Society for Geosciences 2021
}

Correction to: Arabian Journal of Geosciences (2021) 14:357

https://doi.org/10.1007/s12517-021-06675-6

The original version of this paper was published with error. Figures 4 and 5 were interchanged. Also, Fig. 12 caption is incomplete. Given in this article are the correct figures and captions.

The original article has been corrected.
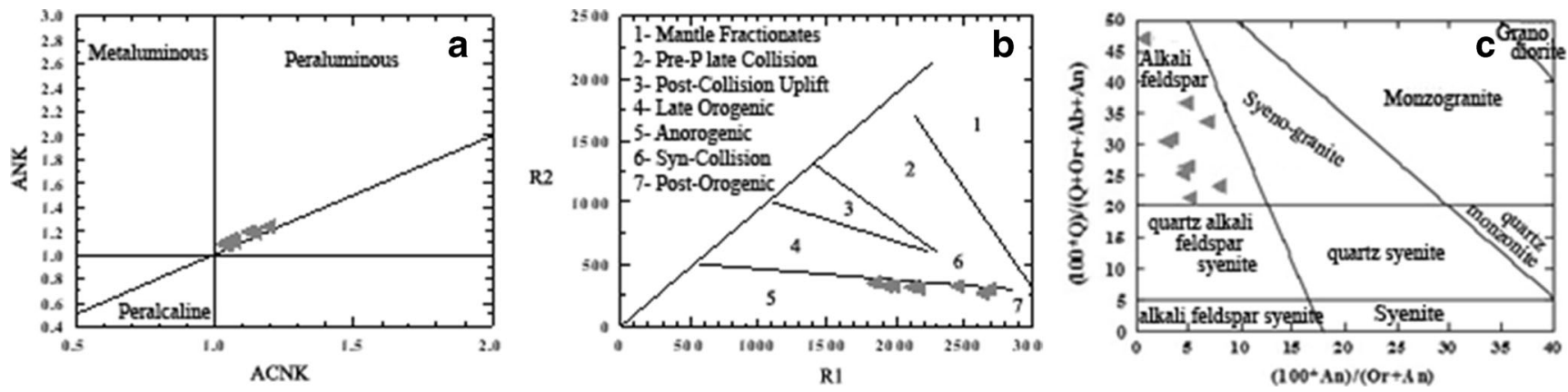

Fig. 4 Plots for the studied granites using geochemical diagrams of a alumina saturation index diagram of Rollinson (1993), b R1-R2 rock classification diagram of De La Roche et al., (1980), c Streckeisen \& Le Maitre (1979

The online version of the original article can be found at https://doi.org/10. 1007/s12517-021-06675-6

Ahmed Hamis

tizihamis@gmail.com

1 Mouloud Mammeri University of Tizi Ouzou, F.B A S, Tizi Ouzou, Algeria

2 Metallogeny and Magmatism Laboratory, (USTHB), Algiers, Algeria
3 Laboratoire Géomatériaux et Environnement, EA 4508, Université Paris Est Marne La Vallée, Champs-sur-Marne, France

4 Intitut National Polytechnique de Lorraine, UMR 7566 du CNRS, Nancy, France 

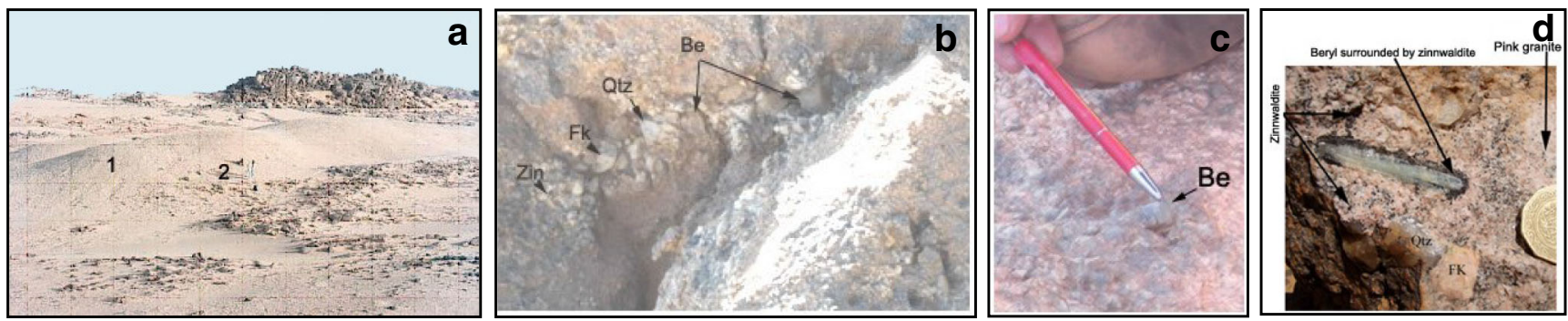

Fig. 5 a Outcrop of a pegmatite underlying a quartz vein (1-vein of quartz, 2-beryl bearing pegmatite), b Beryl in pockets hosted in pink biotite-granite, $\mathbf{c}$ Beryl in pocket in porphyric biotite-granite, $\mathbf{d}$ Beryl surrounded by zinnwaldite in a miarolitic pegmatite in pink biotite-granite
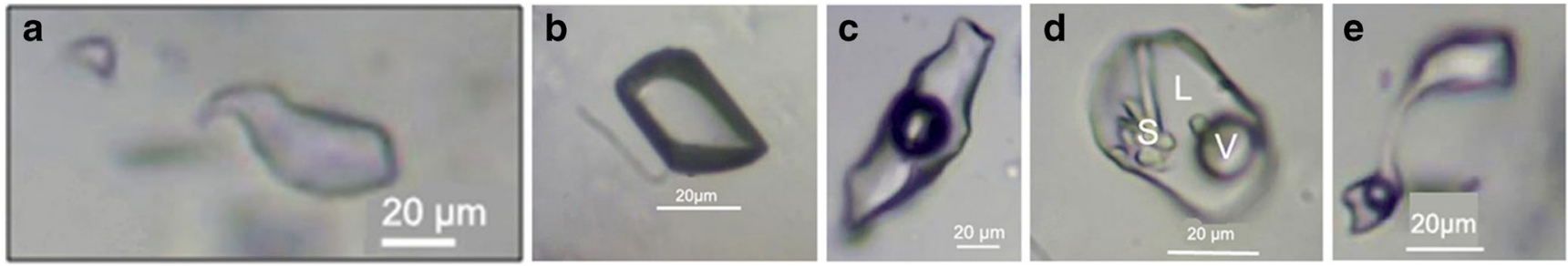

Fig. 12 Fluid inclusion types: monophase liquid (a), monophase vapor (b), two-phase liquid-vapor (c), three-phase liquid-vapor-solid (d), necking-down (e) 